\title{
The Role of Indonesian Youth Diaspora in Malaysia To Maintaining National Defence
}

\author{
Aldina Syafitri Siregar ${ }^{1}$, Margaretha Hanita ${ }^{2}$ \\ \{aldina.syafitri@ui.ac.id ${ }^{1}$, margaretha.hanita@gmail.com ${ }^{2}$ \} \\ ${ }^{1,2}$ School of Strategic and Global Studies, Universitas Indonesia, Jakarta, Indonesia
}

\begin{abstract}
At first, the word Diaspora was more associated with the existence of the Greeks who were driven from their countries and lived scattered in various parts of the earth. Gradually the meaning of the word Diaspora extends, not only to the existence of the Greeks. The word Diaspora can be use for natives brought to their colonies, such as Indonesians who went to the Netherlands during the colonial period. Globalization facilitates the mobility of diaspora, for example, by studying and working abroad or marrying foreign citizens. Based on data from the Indonesian Embassy in London in 2011, Malaysia was ranked third with the most significant number of Indonesian students with a total of 13627. How did the Indonesian diaspora in Malaysia play a role in maintaining national defense?
\end{abstract}

Keywords: Diaspora, Globalization, maintaining national defense

\section{Introduction}

The term diaspora comes from the Greek diaspora's, which means scattering of seeds. ${ }^{1}$ At first, the word Diaspora was more associated with the existence of the Greeks who were driven from their countries and lived scattered in various parts of the earth. Gradually the meaning of the word Diaspora extends, not only to the existence of the Greeks. The word Diaspora can be use for natives brought to their colonies, such as Indonesians who went to the Netherlands during the colonial period.

In the era of globalization, the spread of the diaspora occurred voluntarily and independently. The critical indicator of globalization is a rapid increase in all movements/flows, starting from the flow of money and trade, but also democratic values, cultural products, and the media, and the most important in the context of population migration is the flow of people. ${ }^{2}$ Globalization facilitates the mobility of diaspora, for example, by studying and working abroad or marrying a Foreign Citizen.

\footnotetext{
${ }^{1}$ Karim, H. K. (2003). The media of diaspora. London, UK: Routledge.

${ }^{2}$ Castles, S; H. De Hass, dan M.J. Miller. 2014. The Age of Migration: International Population movements in the modern world. New York: The Guilford Press.
} 
Table 1. Data BNP2TKI

\section{PENEMPATAN TENAGA KERJA INDONESIA BERDASARKAN 25 NEGARA} PERIODE TAHUN 2011 S.D 2016

\begin{tabular}{|c|l|c|c|c|c|c|c|}
\hline \multicolumn{2}{|c}{ NEGARA } & 2011 & 2012 & 2013 & 2014 & 2015 & 2016 \\
\hline 1 & MALAYSIA & 134.266 & 134.088 & 150.248 & 127.812 & 97.621 & 87.616 \\
\hline 2 & TAIWAN & 78.865 & 81.071 & 83.544 & 82.665 & 75.304 & 77.087 \\
\hline 3 & SAUDI ARABIA & 137.835 & 40.655 & 45.394 & 44.325 & 23.000 & 13.538 \\
\hline 4 & HONG KONG & 50.301 & 45.478 & 41.769 & 35.050 & 15.322 & 14.434 \\
\hline 5 & SINGAPORE & 47.786 & 41.556 & 34.655 & 31.680 & 20.895 & 17.700 \\
\hline 6 & UNITED ARAB EMIRATES & 39.917 & 35.888 & 44.505 & 17.963 & 7.619 & 2.575 \\
\hline 7 & BRUNEI DARUSSALAM & 10.804 & 13.146 & 11.269 & 11.616 & 9.993 & 8.152 \\
\hline 8 & QATAR & 16.616 & 20.380 & 16.237 & 7.862 & 2.460 & 1.355 \\
\hline 9 & KOREA SELATAN & 11.392 & 13.593 & 15.374 & 11.849 & 5.501 & 5.912 \\
\hline 10 & UNITED STATES & 13.749 & 15.353 & 15.021 & 9.233 & 1.029 & 249 \\
\hline 11 & OMAN & 7.306 & 8.836 & 10.719 & 19.141 & 6.766 & 1.014 \\
\hline 12 & BAHRAIN & 4.379 & 6.328 & 5.384 & 5.472 & 2.570 & 123 \\
\hline 13 & ITALY & 3.408 & 3.691 & 3.746 & 1.295 & 1.516 & 851 \\
\hline 14 & JAPAN & 2.508 & 3.293 & 3.042 & 2.428 & 468 & 75 \\
\hline 15 & KUWAIT & 2.723 & 2.518 & 2.534 & 1.714 & 210 & 987 \\
\hline 16 & TURKEY & 1.016 & 1.209 & 1.518 & 1.246 & 1.108 & 498 \\
\hline 17 & CHINA & 1.072 & 1.967 & 2.055 & 915 & 108 & 65 \\
\hline 18 & SPAIN & 1.484 & 1.746 & 1.417 & 889 & 268 & 126 \\
\hline 19 & SOUTH AFRICA & 1.272 & 1.388 & 906 & 587 & 113 & 16 \\
\hline
\end{tabular}

In 2015, the number of Indonesians abroad was around 4.6 million. According to The Indonesian Diaspora Network (IDN) data, currently, the number of Indonesian diaspora is about 6-8 million people. Of that number, about 4.6 million Indonesian citizens abroad and 1.5 million ex-Indonesian citizens and their descendants who live in various countries and their descendants. ${ }^{3}$

Indonesian Diaspora Network (IDN), as an organization that accommodates Indonesian people abroad as well as facilitators for the diaspora contributing to Indonesia's development, can be an effective means of public diplomacy. It is following the characteristics of public diplomacy as a non-governmental group, and its simple form is effective in reducing tension, eliminating fear, and increasing interdependence among the parties. In addition to the Indonesian Diaspora Network (IDN), there are several organizations facilitate the Indonesian community abroad, including; Congress of Indonesian Diaspora (CID), Indonesian Diaspora Foundation (IDF), and the International Indonesian Scientific Association (I4).

The majority of Diaspora members are Indonesian youth who study and work abroad. According to the 2014-2017 UNDP Youth Strategy 47, youth are community groups in the age range of 15-35 years. According to WHO, ages 10-24 are classify as young people. According to Law Number 40 of 2009 concerning Youth Article 1 Paragraph (1), defines that:

"Youth are Indonesian citizens who enter important periods of growth and development aged 16 (sixteen) to 30 (thirty) years".

The implementation of the Conference of Indonesia Diaspora Youth (CIDY) on 13-15 August 2018 gave birth to new ideas for Indonesia. Dino Patti Djalal, as Chairperson of the Indonesia Diaspora Network (IDN), gathered the young generation of Indonesian diaspora from 34 provinces to design the Vision of Indonesia 2045.

Indonesia's Vision 2045 is considered as a continuation of the Youth Pledge. The Youth Pledge, which was hold in 1928, has resulted in an independent Indonesia. It is hope that the

${ }^{3}$ Bachtiar, Imelda, "Diaspora Indonesia bakti untuk Negeriku”, Jakarta: PT. Kompas Media Nusantara, 2015. 
Vision of Indonesia 2045 as a milestone for Indonesia, which in 2045 Indonesia will commemorate 100 years of independence.

However, according from the actions of the youth of the Indonesian diaspora who chose to study and study abroad rather than at home is a doubt of some circles. Young Indonesian diaspora members who come from mixed marriages with Indonesian citizens must also be consideration. Will the 2045 Indonesian Vision formed by the young diaspora come true? Will the Vision of Indonesia 2045 be a big scourge for Indonesian citizens by providing leadership relay to the descendants of mixed marriages with Indonesian citizens?

\section{Literature Review}

\subsection{Diaspora Theory}

According to Wahlbeck: 2002, the diaspora was initially only used to refer to Jews who were drive out of their home countries. ${ }^{4}$ According to Singgih Tri Sulistiyono: 2011, diaspora and migration are a phenomenon that often found in the history of the nations of the world, including Indonesia.

According to Dino Patti Djalal, there are four groups of Indonesian Diaspora, and the first are Indonesian citizens who live abroad (Indonesian passport holders) legally; second is Indonesian citizens who have become foreign citizens due to the naturalization process and no longer have an Indonesian passport. Meanwhile foreign citizens who have parents or ancestors who came from Indonesia are in the third category. And finally, some foreigners have no ancestral ties with Indonesia at all but have an extraordinary love for Indonesia, such as Paul Wolfowitz (Former Ambassador of the United States of America to Indonesia), who is fluent in Indonesian as an example of the fourth group.

Based on the above definition, it can be concluding that a diaspora is a native citizen of a country that has moved and settled in another country.

\subsection{Youth Theory}

According to WHO in Carlito Sarwono: 2008, aged 10-24 years are classified as young people, while adolescents or adolescence are in the age group of 10-19 years.

Meanwhile According to Mukhlis: 2007, "youth is a generation whose shoulders are burden with a variety of expectations, especially from others".

According to Law Number 40 of 2009 concerning youth article 1 paragraph (1), defines that "Youth are Indonesian citizens who enter an important period of growth and development aged 16 (sixteen) to 30 (thirty) years". 5

Based on the above understanding, it can be concluding that youth are men aged 16-30 years who are biologically showing signs of maturity.

The younger generation has a very vital position and role in the life of the Indonesian nation. It is base on the part of youth as contained in RI Law No. 40 of 2009 concerning Youth, which reads the youth plays an active role as a moral force, social control, and agents of change in all aspects of national development. The Youth is one of the keys to the birth of the Indonesian

\footnotetext{
${ }^{4}$ Wahlbeck, O. 2002, 'The concept of diaspora as an analytical tool in the study of refugee communities', Journal of Ethnic and Migration Studies 28 (2): 221-238.

${ }^{5}$ UU RI No. 40 Tahun 2009 Tentang Kepemudaan
} 
state, which upholds the values of unity above the diversity of the Indonesian people. It can be prove from Indonesian past fact that provide an overview of the vital role of youth, namely the historical event of the Youth Pledge on October 28, 1928, which became the key to the formation of youth power to unite against the Dutch colonial occupation. In this declaration, an agreement was reached by young Indonesians as young men who shed one blood, namely the homeland of Indonesia, as young people with one nation, namely the Indonesian people, and one language, Indonesian.

The first Indonesian president, Sukarno, once said, "Give me 1,000 parents, I will undoubtedly pull all the excitement from its roots. Give me ten young men; surely I will shake the world." This is a whip that youths are the main key in the struggle towards the improvement of the Indonesian state, which is one in Sumatra. Based on the characteristics of youth as in RI Law No. 40 of 2009 concerning youth article 6 namely "having the spirit of struggle, volunteerism, responsibility, and chivalry, as well as having a critical, idealistic, innovative, progressive, dynamic, reformist, and futuristic nature." Youth with such characteristics make it have an essential role in the social dynamics of Indonesia amid the flow of social change that continues to plague Indonesia.

The role of youth is essential not only because the majority of Indonesia's population is currently young; but essential for various reasons, including first, youth are the next generation who will continue the ideals of the nation's struggle. Second, the continuity of the nation's history and culture, the style, and color of a nation's future will primarily determined by the direction of preparation or guidance and development of the young generation at this time. Third, ensuring the sustainability of the country's fundamental values. It seen from the spirit of youth, namely the youth oath of 1928, the proclamation of 1945, Pancasila, and the 1945 Constitution.

\subsection{Theory of National Resilience}

According to M. Bambang Pranowo: 2001, Civic Resilience is a condition of national dynamics that covers all aspects of national life that are integrated and able to develop national strength in facing all challenges, threats, obstacles and disturbances that come from outside or from within, which are directly or indirectly, as an effort to ensure the survival of the nation and the State in achieving shared ideals. 6

According to Johny Lumintang: 2001, Indonesia's National Resilience is a dynamic condition of the Indonesian nation, which includes all aspects of integrated national life. 7

According to Kansil: 1986, National Resilience is the ability and resilience of a Nation to be able to guarantee its survival towards the glory of the Nation and State. 8

In essence, National Resilience is the ability and resilience of a nation to ensure its survival. The implementation of National Resilience is carried out through a security and welfare approach. Security is the ability to protect the nation's existence, and protect the nation's noble values against all threats from within and from outside. Meanwhile welfare is used to realize resilience in the form of a nation's ability to grow and develop its national values into a just and equitable prosperity, both spiritual and physical.

${ }^{6}$ Pranowo, M. Bambang. 2001. Multidimensi Ketahanan Nasional. Jakarta: Pustaka Alvabet Anggota IKAPI.

${ }^{7}$ Lumintang, Johny. 2001. Pendidikan Kewarganegaraan. Jakarta: PT Gramedia Pustaka Utama

${ }^{8}$ Kansil. 1986. Aku Pemuda Indonesia Pendidikan Politik Generasi Muda, Jakarta: Balai Pustaka. 


\section{Methodology}

\subsection{Data Collection}

This research was conducted in 2015 by Haning Romdiati with the title Globalization of Migration and the Role of Diaspora: A Literature Review. The research contains the phenomenon of globalization and its context on the formation and role of the diaspora in the country of origin. Although there is no clear evidence yet, it assumed that there is an acceleration of international migration flows as part of the globalization process. This acceleration seen as one of the factors that contribute to the formation and strengthening of the diaspora.

This research was conducted in 2016 by Ikhwan Izzan with the title Position and Legal Status of the Diaspora in the Citizenship Legal System in Indonesia. This study aims to find out and answer questions about how the legal status and position of the Diaspora in the citizenship legal system in Indonesia, and to know whether the Indonesian Diaspora can be given dual citizenship in the Indonesian citizenship legal system, and to find out the obstacles and problems of Indonesia in providing dual citizenship and to know the formulation of regulations on citizenship Legislation concerning dual citizenship in Indonesia.

Helda Risman conducted this research, Gde Sumertha KY, Pudjo Widodo with the title Strategic Policy for Empowerment of the Indonesian Diaspora for National Defense. The conceptual defense of the Indonesian state is construction in a universal defense system by mobilizing all citizens throughout the Republic of Indonesia. Indonesian Diaspora is an Indonesian citizen who lives and has activities overseas. With a total of around 8 million, spread across various countries, professional diversity, transnational communities, the Indonesian Diaspora has the potential to be empowered for national defense. On the other hand, the challenges and threats faced today are influence by the complex dynamics of influential developments in the strategic environment. The existence of the Indonesian Diaspora has been sporadically developed, free, and lacking in guidance in functional nationalistic entities.

\subsection{Data Analysis}

This research requires primary data sources and secondary data sources. Primary data sources, data obtained directly through in-depth interview techniques to informants relating to the role of the Indonesian youth diaspora in Malaysia in maintaining national resilience. This study will also use structured interviews to support the data obtained in interviews with informants.

Secondary data sources are data sources obtained from studies conducted previously, which still have a relationship with the role of the youth diaspora in maintaining national resilience. This data (documents) in the form of journals and final assignments that have relevance to the issues discussed in this study.

Based on the qualitative approach used in this study, researchers need primary and secondary data. It meet the needs of primary data, interview techniques will be carried out. Interviews will be conducted on the parties involved and related to research issues, namely the role of the Indonesian youth diaspora in Malaysia in maintaining national security. Interviews are expected to be conducted directly with speakers connected to the research problem. This study will also use structured interviews for the needs of primary data; the data obtained will be used as additional data to analyze the role of young Indonesian diaspora in Malaysia in maintaining national security. 
The need for secondary data sources will do by studying literature or library research. The author will read documents or literature relating to research problems. Data read can be accessed online and offline in the form of official papers, books, scientific journals, newspapers, and other media.

The data obtained by the author, both primary data and secondary data will be analyzed based on the research issues raised in this study. Primary data and secondary data can be mutually reinforcing data to be the basis of the arguments written by researchers in this study.

\section{Results and Discussion}

Being part of the big family of Indonesian Diaspora who are overseas students, especially in Malaysia, is a matter of pride and grace from Allah Almighty, which cannot yet be felt by most Indonesian students. Naturally the public's expectations of the presence of Indonesian students abroad are very high for them to return to make improvements and changes in the Indonesian state for the better. It is in line with the mandate of the founder of this nation, as stated in the opening of the 1945 Constitution, which is to educate the nation's life and participate in carrying out world order and social justice. Therefore, the Indonesian Student Association (PPI) Malaysia is present to accommodate the aspirations and movements of Indonesian students in Malaysia to take part in educating the life of the nation, wherever they are, through measured and planned PPIM work programs. For this reason, the Mid-year Responsibility Report is hold as a material for evaluating the management performance for a half year period to be improved in the next half-year period.

Management of PPIM 2018/2019 carries the Vision:

"Making PPIM as a shared house to build a scientific treasure, work, creativity, innovation, collaboration, dedication and family among PPI branches and Indonesian students throughout Malaysia"

In realizing this vision, three missions made as follows:

- Build a trustworthy and professional organization to assist and encourage Indonesian students to gain knowledge and information, continue and celebrate studies in Malaysia.

- Facilitating and connecting the potential of work, creativity, innovation, community service, and collaboration among branch, students, alumni, Consulate General, Indonesian Embassy and the Ministry in the fields of research, science, technology, education, social, religion, arts and culture, sports, and tourism.

- Strengthen kinship through educational activities, community service, social and religious affairs, arts and culture, sports, and recreation.

From this mission, several work programs were born as a form of implementation of each task that carried. Mission 1 gave birth to work applications such as website improvement in adding content that provides factual information, news, scholarships, and scientific articles. Besides, we also make documentary videos about the lives of Indonesian students on every campus, both public and private, in Malaysia. Not only that, Alhamdulillah, we also succeeded in publishing an ISBN book, the work of Indonesian students in Malaysia in telling interesting stories and failing to succeed in achieving their goals to study in Malaysia and contribute from neighboring countries for Indonesia and also Call for Article and PPIM Scientific Writing 
Contest where Indonesian students at all levels of education can channel their knowledge according to their fields to share with other students. In its distribution, we made a book review webinar "From the neighboring country for my people" and also raised topics of hot issues that occurred to be discussed by experts so that they supported the first mission of encouraging the acquisition of knowledge and information.

Mission 2 gave birth to work programs such as Young Entrepreneurship Training and StartUp Competition, where we connected the potential of creativity and work of the nation's children in the form of technology-based business to be introduced to the world and be compared. The procurement of the PPIM Tour and Travel platform as a forum to facilitate collaborative, academic, and recreational activities between universities in Indonesia to Malaysia. Besides, the PPIM Meets PPI Branch program is also part of our innovation in connecting and uniting steps in the success of useful applications in the branch to collaborate with fellow PPI Branches. We also partner with external institutions to support our activities, such as with Bank Muamalat Indonesia and Raja Zarith Sofiah Foundation, in facilitating Indonesian students who want to intern and find work.

Mission 3 gave birth to work programs such as teaching PPIM. Through this program, Indonesian students are invited to channel their knowledge and skills to fellow overseas brothers who have not yet received adequate education access and also to be able to foster a spirit of devotion and kinship among fellow children of the nation abroad. Even at this time, we have opened. We are donating 101 school clothes, donating 1000 books, caring about the tsunami disaster in the Sunda Strait, and Palu to ease the burden on domestic relatives and Law Education to understand the younger generation of the importance of fair and equitable law. Besides, in strengthening family ties, PPIM also welcomed and attended religious festivals such as Eid alFitr and Eid al-Adha, as well as Christmas and participated in the distribution of qurbani meat in the village in cooperation with artiqurban.id. And lastly, we have also carried out OBIM to hone talent and foster a sense of kinship between PPI branches in futsal training activities together at APU.

\section{Conclusions and Recommendations}

We have made many collaborations and innovations in improving quality and managing the implementation of PPIM's work programs for the 2018/2019 period. During unpleasant issues that hit early in the management of this period, it did not dampen the enthusiasm, tempo, and quality of the management's work in succeeding the work agenda for the mutual benefit both felt by the administration itself and others. Gratefully with the implementation of work programs, PPIM won an award as a Contributive State PPI. It is an achievement that has not been felt by a union organization that is 20 years old. Thank you and congratulations to all of us, the management of PPIM 2018/2019, for their dedication and enthusiasm to contribute. Of course, in its implementation, there are still many shortcomings that need to be evaluated, such as the level of sensitivity and initiative of the committee, the activeness, and concern of fellow management, and the level of willingness to sacrifice without calculations so that it needs to increase again. Also, it strengthened PPIM's relations with external parties such as the Indonesian Embassy, Indonesian Consulate General, and the Governments of Indonesia and Malaysia to be able to bridge the two Countries. Hopefully, the next- half year management can be further maximize with better levels of quantity and quality. God willing, more significant programs await the administration of this period, such as the Leadership Camp, Asean Youth 
Conference, Cultural Events, Journalistic Workshop, Legal Rights for Foreign Migrants Workshop, XXI PPIM Congress, and other work programs.

\section{References}

[1] Bachtiar, Imelda, "Diaspora Indonesia bakti untuk Negeriku", Jakarta: PT. Kompas Media Nusantara, 2015.

[2] Bogan, Bogdan R., and Biklen, S, 1992. Qualitative Research for Education. Boston. MA: Allyn and Bacon.

[3] Castles, S; H. De Hass, dan M.J. Miller. 2014. The Age of Migration: International Population Movements in the modern world. New York: The Guilford Press.

[4] Cresswell, J.1998. Research Design: Qualitative and Quantitative Approaches. Thousand Oaks"CA: Sage Publications.

[5] https://www.kompasiana.com/virays/551788baa33311ae07b65f0a/diaspora-indonesia-sebuahpotensi-besar. Diakses pada Tanggal 13 April 2019, time of 19.02 WIB.

[6] Kansil. 1986. Aku Pemuda Indonesia Pendidikan Politik Generasi Muda, Jakarta: Balai Pustaka.

[7] Karim, H. K. (2003). The media of diaspora. London, UK: Routledge.

[8] Khalik, Nur. 2010. Kepemimpinan Kaum Muda. Klaten: Cempaka Putih, 2010.

[9] Lumintang, Johny. 2001. Pendidikan Kewarganegaraan. Jakarta: PT Gramedia Pustaka Utama.

[9] MD, Sagimun. 1989. Peranan Pemuda Dari Sumpah Pemuda Sampai Proklamasi. Jakarta: Bina Aksara.

[10] Pranowo, M. Bambang. 2001. Multidimensi Ketahanan Nasional. Jakarta: Pustaka Alvabet Anggota IKAPI.

[11] Tri Sulistiyono, Singgih, "Diaspora dan Proses Formasi Keindonesiaan: Sebuah Pengantar Diskusi”, Makalah dipresentasikan pada Konferensi Nasional Sejarah IX, Jakarta, 5 - 7 Juli 2011).

[12] UU RI No. 40 Tahun 2009 Tentang Kepemudaan

[13] Wahlbeck, O. 2002, 'The concept of diaspora as an analytical tool in the study of refugee communities', Journal of Ethnic and Migration Studies 28 (2): 221-238. 